\title{
FIRST DOCUMENTED BREEDING RECORDS OF CATTLE EGRETS IN MANITOBA
}

RON BAZIN, Canadian Wildlife Service, 150 - 123 Main Street, Winnipeg, MB, R3C 4W2, E-mail: ron.bazin@ec.gc.ca

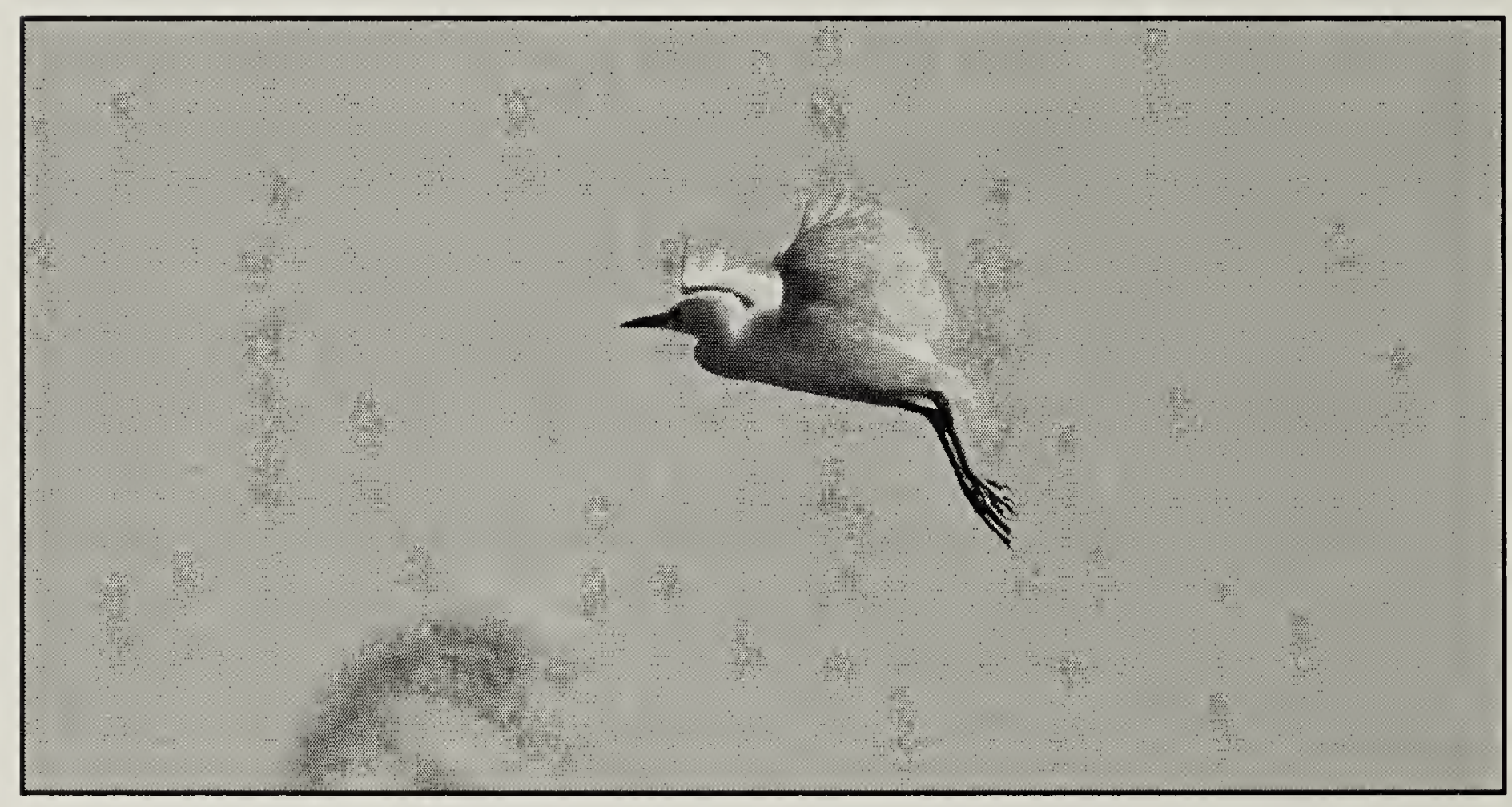

Adult Cattle Egret flying over the Plum Lakes colony, 1 September 2005.

Ron Bazin

The Cattle Egret is an Old World species that exhibits strong dispersal tendencies. ${ }^{1}$ This extensive wandering behaviour, which is common in many heron species, has resulted in a well-documented, nearly worldwide range expansion for the species, which presently occupies every continent except Antarctica. ${ }^{12}$ Within each continent, its range is nonetheless confined mostly to tropical and temperate zones, avoiding areas with extreme climates. ${ }^{12}$

On the North American continent, the Cattle Egret was first observed in southern Florida in 1941, officially documented with photographs in 1952 and found nesting the following year. ${ }^{12}$ In the fall of 1952, the first reported Cattle Egret in Canada was seen off the Grand Banks of Newfoundland. ${ }^{4}$ In just over 50 years, Cattle Egrets have spread out over most of North America, with confirmed sightings in all but two of the contiguous U.S. states, and in all Canadian provinces and the Northwest Territories. ${ }^{7,} 12$

Manitoba recorded its first sighting in May 1961, between Alexander and Griswold. ${ }^{9}$ Cattle Egrets were subsequently observed with increasing regularity through the 
second half of the 1970s. Observations decreased sharply during the 1980s and early 1990s, but greater numbers were observed in the late 1990 s and increasingly up to 2005 , a year of unprecedented record counts of 315 birds in the Maple Lake-Oak Lake area, 292 at Whitewater Lake, and an estimated provincial total of up to 1000 birds. ${ }^{6,8}$

With such high numbers in recent years in Manitoba, breeding was strongly suspected, particularly at Whitewater Lake where, in 2003, birds were seen carrying nesting material, and where a colony was apparently observed but not reported (C. Meuckon, 27 June 2006, pers. comm.). ${ }^{5}$ Previously breeding had only been confirmed in two provinces Ontario (1962) and Saskatchewan (1981).3,11 With the current breeding records reported in this paper, Manitoba becomes the third province in Canada to officially document nesting Cattle Egrets.

In late summer of 2005, I was alerted by Canadian Wildlife Service (CWS) staff to a possible egret colony at the Plum Lakes, just south of Oak Lake. On 1 September 2005, I visited the area by airboat with other CWS staff and confirmed that it was indeed a successful Cattle Egret colony, within which Black-crowned Night-Herons were also nesting. Cattle Egrets commonly nest within multi-species heron colonies, and may possibly follow individuals of other species to new breeding areas. ${ }^{2,3,10-12}$ Throughout the colony, juvenile Cattle Egrets were observed at various stages of development, from completely down covered to near fledging, with the latter birds comprising the majority of the young observed. There were, on average, 23 young seen per nest.

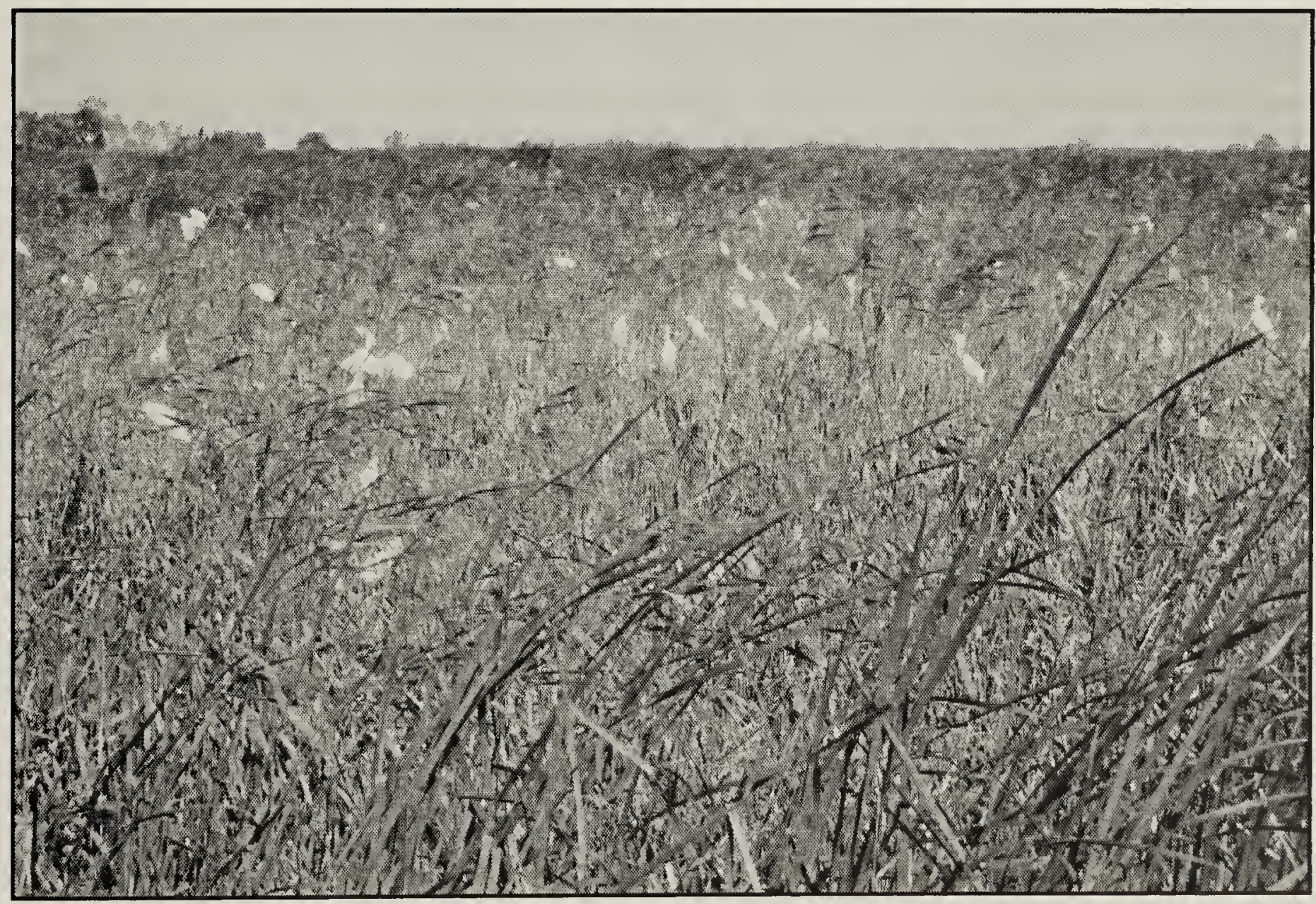

Small portion of the Cattle Egret colony at the Plum Lakes, 1 September 2005. Note that Cattle Egrets are nesting within the Reed Grass area, which is surrounded by an extensive cattail stand. 
The colony was in a moderately dense stand of primarily dead Reed Grass (Phragmites australis), $100 \pm 5$ $\mathrm{cm}$ in height above the water. The Reed Grass stand was completely surrounded by a very dense and extensive stand of even higher cattail (Typha sp.), which formed a barrier that was difficult to penetrate, undoubtedly affording some protection for the colony. Very similar habitat characteristics were observed at a colony on the J. Clark Salyer National Wildlife Refuge in North Dakota in 1972 , approximately $120 \mathrm{~km}$ south of the present colony. ${ }^{2}$

Nests were constructed primarily of dead Reed Grass stalks and were supported on dead stem growth approximately $75 \mathrm{~cm}$ above the water. The average water depth at the colony site was $56 \pm 6 \mathrm{~cm}$. Cattle Egret and Black-crowned Night-Heron nests were intermixed within those areas of the colony that were observed and collectively formed a moderately dense nesting arrangement. A Global Positioning System unit was used to mark the outline of the colony and measure its total area, which was calculated to be approximately 4000 $\mathrm{m}^{2}$. After taking measurements and photos, we retreated from the colony to avoid further disturbance.

On 30 September 2005, I returned to the colony to obtain a nest density estimate. Approximately 20 Cattle Egrets were present at the colony, but all left upon my arrival. The greatest difficulty was attempting to differentiate between Cattle Egret and Blackcrowned Night-Heron nests. In general, based on carcasses of juvenile birds still present in the nests, Cattle Egret nests appeared to be built much higher above the water than those of Black-crowned Night-Herons, a phenomenon I also observed in other
Cattle Egret colonies in the summer of 2006. There'is, however, great variability in both nest site selection and construction for these two species, with little information in the literature to differentiate between nest types, so this method of nest differentiation is by no means certain. Within a $600 \mathrm{~m}^{2}$ plot established on the west end of the colony, I counted a total of 112 nests of which 85 were presumed to belong to Cattle Egrets, giving a nest density of 0.14 nests $/ \mathrm{m}^{2}$. This is very close to a minimum nest density estimate of 0.12 nests $/ \mathrm{m}^{2}$ for a colony in Texas. ${ }^{12}$ Assuming an even distribution of nests throughout the colony, this would result in an estimate of 560 Cattle Egret nests.

It is difficult to determine how accurate this estimate might be, given the uncertainty in differentiating between nests of the two species (some nests counted as Cattle Egret nests could have actually been Blackcrowned Night-Heron nests). However observations made during the first visit did indicate predominantly "white" birds in all those areas where visual observations were made. As well, it is unknown whether the nest density obtained within the sample plot is representative of the entire colony. Although the actual number of Cattle Egret nests will never be known, it is safe to say that given the unprecedented numbers observed in the Maple Lake - Oak Lake area, Cattle Egret nests likely numbered in the hundreds within this first documented breeding colony.

The Cattle Egret colony at the Plum Lakes was visited on 6 July 2006 and found to be active again. This time the colony site consisted primarily of dense, live Reed Grass, precluding any larger scale view of adults on nests. Two nests were, however, 


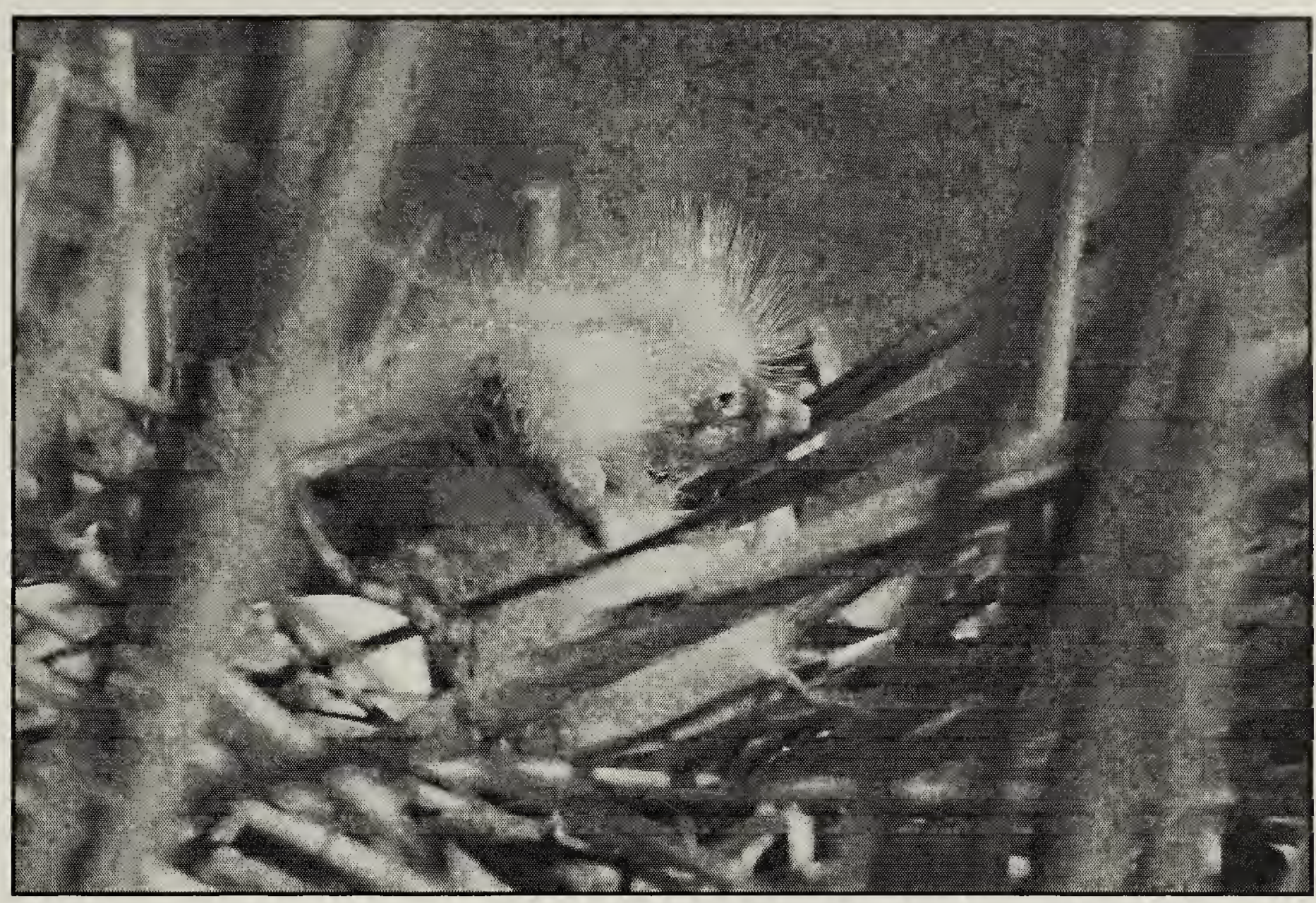

Downy Cattle Egret chicks with two unhatched eggs at a new colony at the Plum Lakes in southwest Manitoba, 1 September 2005.

Ron Bazin

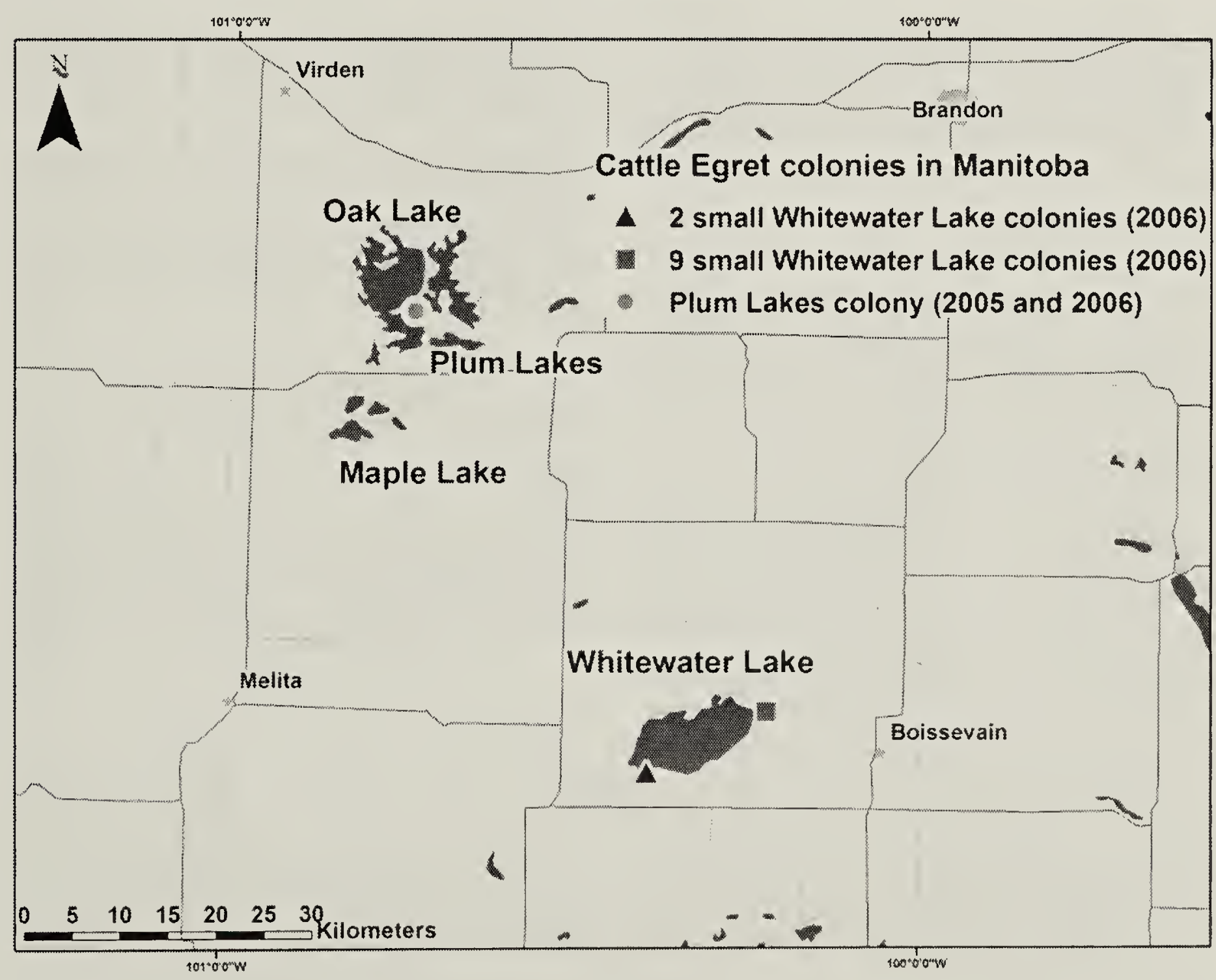

Figure 1. Cattle Egret colonies in Manitoba. 
observed from the airboat at the edge of the colony, and approximately 75 adult Cattle Egrets flew from the colony upon our arrival. In addition to this colony, a total of 11 separate small colonies, ranging from two to 14 birds, were observed on 4 July 2006 at Whitewater Lake, approximately $55 \mathrm{~km}$ southwest of the Plum Lakes. These small colonies were located at the west (two colonies) and east (six colonies) ends of the lake, and in the adjacent impoundment (three colonies), and were all associated with nesting Black-crowned Night-Herons (Figure 1). Approximately 66 Cattle Egrets were observed within the eight colonies in the lake area. The three colonies in the impoundment area were reported to, but not visited by, the author, without any additional information on size or numbers.

Future searches for Cattle Egret breeding colonies should focus on those areas where existing heron colonies, particular Black-crowned Night-Heron colonies, occur close to moist, moderately grazed pastures. Aerial photography could potentially be used during the late incubation/early hatching stage on larger colonies to obtain more reliable nest count estimates within a colony.

\section{Acknowledgements}

The author would like to thank Marc Schuster for information concerning the existence of the colony, Laura Beaudoin and Nathan Wiebe for assistance in the field, and Paul
Goossen for reviewing an earlier draft of this article.

1. ARENDT, W. J. 1988. Range expansion of the Cattle Egret (Bubulcus ibis) in the Greater Carribean Basin. Colonial Waterbirds 11(2): 252262.

2. AUFFORTH, A. 1977. An interesting invader. North Dakota Outdoors 40(11): 24-25.

3. BUERKLE, U. and W. D. MANSELL. 1963. First nesting record of the Cattle Egret (Bubulcus ibis) in Canada. Auk 80(3): 378-379.

4. GODFREY, W. E. 1954. The Cattle Egret at sea off Newfoudland. Canadian Field-Naturalist 68(3): 139-140.

5. KOES, R. F. and P. TAYLOR. 2004. Prairie Provinces. North American Birds 57(4): 506-507.

6. KOES, R. F. and P. TAYLOR. 2006. Prairie Provinces. North American Birds In Press.

7. KUYT, E. 1972. First record of the Cattle Egret in the Northwest Territories. Canadian FieldNaturalist 86: 83-84.

8. MANITOBA AVIAN RESEARCH COMMITTEE. 2003. The Birds of Manitoba. Manitoba Naturalists Society, Winnipeg, Manitoba.

9. PLEWS, D. 1961. Manitoba record of the Cattle Egret. Blue Jay 19: 112.

10. PUTNAM, L. S. 1978. Cattle Egret nesting in Western Lake Erie. Ohio Journal of Science 78(2): 69.

11. RONEY, K. 1982. Cattle Egret nest record for Saskatchewan. Blue Jay 40(3): 163-164.

12. TELFAIR, R. C. II. 2006. Cattle Egret (Bubulcus ibis). In The Birds of North America Online (A. Poole, Ed.). Ithaca: Cornell Laboratory of Ornithology; Retrieved from The Birds of North America Online database: http:// bna.birds.cornell.edu/BNA/account/Cattle_Egret/

"Barred Owl: Who cooks for you, who cooks for you all-I-I?; Warbling Vireo: When I sees one I shall seize one and l'll squeeze it 'till it SQUIRTS!" ; American Goldfinch: Potato-chip, potato-chip." Scott Weidensaul, The Birder's Miscellany, p. 118 